\title{
Karakteristik Fisik dan Organoleptik Susu Segar di Medan Sunggal
}

\section{Physical Characteristics and Organoleptic of Fresh Milk in Medan Sunggal}

\author{
N. Asmaq* dan J. Marisa \\ Fakultas Sains dan Teknologi, Universitas Pembangunan Panca Budi, Medan - Indonesia \\ *Corresponding E-mail: nur.asmaq@dosen.pancabudi.ac.id \\ (Diterima: 17 Januari 2020; Disetujui: 3 Maret 2020)
}

\begin{abstract}
ABSTRAK
Tujuan penelitian ini adalah untuk mengetahui karakteristik fisik dan organoleptik susu yang dijual peternak ataupun outlet susu serta kelayakan susu berdasarkan SNI di Medan Sunggal. Materi yang digunakan pada penelitian ini adalah $15 \mathrm{~L}$ susu sapi segar yang dibeli pada beberapa peternak atau outlet di daerah Medan Sunggal. Penelitian ini menggunakan metode survey dengan uji t dan data dianalisis secara deskriptif. Parameter yang diamati yaitu angka reduktase, uji alkohol, titik didih, $\mathrm{pH}$ dan organoleptik susu segar. Hasil penelitian ini menunjukkan bahwa susu dari peternak ataupun outlet di Medan Sunggal tidak memenuhi SNI 3141.1.
\end{abstract}

Kata kunci: angka reduktase, organoleptik, $\mathrm{pH}$, susu, titik didih, uji alkohol

\section{ABSTRACT}

This research aims to know the physical characteristics and organoleptic of fresh milk that is sold by farmers or milk outlets and milk feasibility based on SNI in Medan Sunggal. The material used in this research is 15 L fresh cow milk purchased at several farmers or outlets in the Medan Sunggal area. This research uses the survey method with a t-test, and data were analyzed descriptively. The observed parameters are reductase figures, alcohol tests, boiling points, $\mathrm{pH}$, and organoleptic fresh milk. The results of this research show that milk from farmers or outlets in Medan Sunggal not suitable SNI 3141.1.

Keywords: Reductase figures, organoleptic, PH, milk, boiling point, alcohol test

\section{PENDAHULUAN}

Salah satu negara berkembang yang memiliki sektor peternakan yang besar adalah Negara Indonesia yang ditandai dengan upaya pemerintah untuk meningkatkan kesejahteraan masyarakat melalui beberapa program seperti swasembada daging dan pengadaan bantuan ternak. Jenis-jenis ternak yang dipelihara yaitu ruminansia (sapi, kambing, domba) dan unggas antara lain ayam, bebek/itik, puyuh dan lain sebagainya. Ternak sapi yang dipelihara oleh peternak di negara ini yaitu jenis potong dan perah.

Sapi perah merupakan jenis ternak yang memiliki produksi utama yaitu susu. Jumlah populasi sapi perah di Indonesia per tahun
2017 adalah 5.448.000 ekor yang tersebar di seluruh wilayah Indonesia. Jumlah ternak ini meningkat dari tahun 2016 yang berjumlah 5.339.000 ekor. Seiring bertambahnya jumlah ternak yang dipelihara, jumlah produksi susu sapi ini pada tahun 2017 adalah 920.093 ton yang mengalami peningkatan mencapai $0,81 \%$.

Penyebaran sapi perah telah sampai di wilayah Provinsi Sumatera Utara. Jumlah populasi ternak ini meningkat sebanyak 1.400 ekor pada tahun 2016 menjadi 1.948 ekor pada tahun 2017. Beberapa daerah di provinsi ini juga telah memelihara jenis ternak penghasil susu ini, seperti Kota Medan. Jumlah populasi di kota ini sebanyak 274 ekor. Jumlah populasi ternak akan sangat mempengaruhi jumlah 
produksi susu yang dihasilkan.

Kandungan protein yang tinggi pada susu menjadikan produk hewani ini tergolong produk bernilai gizi yang tinggi. Selain nutrisi ini, komposisi susu terbesar adalah kadar air yang mencapai $80 \%$ diikuti oleh nutrisi lainnya seperti laktosa, kalsium, fosfor dan mineral lainnya. Susu murni merupakan cairan yang diambil dari sapi perah yang sedang laktasi dengan kandungan alami yang tidak dimodifikasi dengan bahan-bahan lainnya.

Kandungan susu bisa berkurang atau berubah apabila diamati dengan cermat. Misalnya seperti perubahan warna pada pada susu. Warna putih kekuningan susu bisa berubah dengan penambahan beberapa bahan lain yang bertujuan untuk memberikan efek warna putih atau kuning terhadap susu yang akan dijual. Selain itu, aroma susu yang khas juga bisa perubahan dengan penambahan bahan-bahan lain, juga sama halnya dengan rasa susu yang bisa ditambahkan dengan perasa seperti air tajin. Hal-hal seperti ini merupakan salah kecurangan-kecurangan yang banyak didapatkan di outlet penjual susu segar salah satunya outlet susu di Kecamatan Medan Sunggal.

Pemalsuan susu yang sering dilakukan adalah penambahan susu dengan air yang bertujuan untuk menambah volume susu yang dihasilkan, pencampuran susu dengan susu yang sudah tidak layak konsumsi atau basi juga dilakukan beberapa penjual susu. Selain itu, penambahan susu dengan tepung untuk menambah kekentalan susu, penambahan santan ke dalam susu dan yang paling berbahaya adalah penambahan bahan kimia ke dalam susu yang dijual. Selain pemalsuan susu menggunakan bahan-bahan tersebut, produk ini juga dapat rusak karena kontaminasi mikroorganisme. Salah satu kontaminan susu adalah mikroorganisme yang mengkontaminasi pada saat proses pemerahan seperti pemerah, ternak, alatalat yang digunakan yang tidak dibersihkan sebelum digunakan. Pratiwi (2018) menemukan $50 \%$ peternak yang memerah susu di Kota Medan yang tidak higienis dalam pengerjaan dana ditemukan 1 sampel susu positif bakteri Salmonella sp. Oleh karena itu, harus dilakukan pengujian karakteristik susu secara fisik dan organoleptik untuk megetahui tingkat kesegaran susu yang dijual di outletoutlet susu di sekitaran Kota Medan dengan metode sederhana.

Penelitian ini dilakukan dengan tujuan; 1) untuk mengetahui karakteristik fisik dan organoleptik susu segar yang dijual di outletoutlet susu di daerah Medan Sunggal, dan 2) untuk mengetahui kelayakan susu yang dijual di outlet-outlet susu di daerah Medan Sunggal sesuai dengan SNI.

\section{METODE}

Penelitian ini dilaksanakan di Laboratorium Teknologi Hasil Pertanian Universitas Pembangunan Panca Budi Medan. Materi pada penelitian yang dilakukan adalah susu sapi sebanyak $15 \mathrm{~L}$, masing-masing susu sapi diambil $1 \mathrm{~L}$ dari peternak dan outlet-outlet susu di daerah Medan Sunggal, alkohol 70\%, methylene blue, bunsen, tabung reaksi, rak tabung reaksi, pipet tetes, kapas, erlenmeyer, $\mathrm{pH}$ meter, inkubator, batang pengaduk, gelas ukur, dan kapas.

Pelaksanaan penelitian dimulai dengan mempersiapkan susu sapi dan kambing yag dibeli dari peternak dan outlet-outlet susu di daerah Medan Sunggal. Susu yang dibeli adalah susu hasil pemerahan pagi dan sore hari. Selanjutnya variabel penelitian diuji di laboratorium. Variabel yang diamati pada penelitian ini adalah angka reduktase, uji alkohol, uji titik didih, nilai $\mathrm{pH}$ dan organoleptik.

\section{Uji Reduktase (Modifikasi Susilawati et al.,} 2013)

Sepuluh milliliter susu dimasukkan ke dalam tabung reaksi steril. Kemudian, 2 $\mathrm{ml}$ methylene blue ditambahkan kemudian dihomogenkan, ditutup rapat menggunakan kapas. Lalu, dimasukkan ke dalam inkubator $\left(37^{\circ} \mathrm{C}\right)$. Waktu perubahan sampel diamati dan dicatat. 


\section{Uji Alkohol}

Susu dimasukkan ke dalam tabung raksi sebanyak $5 \mathrm{ml}$. Selanjutnya, sebanyak $5 \mathrm{ml}$ alkohol 70\% ditambahkan (1:1). Perubahan pada susu diamati (apabila terjadi penggumpalan maka susu tersebut telah rusak dan sebaliknya).

\section{Uji Titik Didih}

Sebanyak $5 \mathrm{ml}$ susu dimasukkan ke dalam tabung reaksi. Tabung reaksi dipanaskan menggunakan bunsen sampai mendidih. Proses pemanasan dimati (susu menggumpal di dinding tabung ' + ' susu tidak baik, dan sebaliknya).

\section{Uji pH}

Susu dimasukkan ke dalam erlenmeyer sebanyak $25 \mathrm{ml}$. Bagian elektroda dicelupkan dengan posisi menggantung ke dalam susu. Apabila angka pada monitor sudah stabil, selanjutnya dicatat.

Metode yang digunakan pada penelitian ini adalah metode survey dengan uji t. Hasil yang diperoleh dianalisis secara deskriptif. Rumus matematis uji t menurut Masrizal (2010) sebagai berikut:

$$
t=\left|\frac{\bar{x}-\mu}{s / \sqrt{n}}\right|
$$

Keterangan: $\bar{x}$ : Rataan hitung

$$
\begin{aligned}
& \mu: \text { Peluang } \\
& \mathrm{s}: \text { standar deviasi } \\
& \mathrm{n}: \text { banyaknya pengamatan }
\end{aligned}
$$

\section{HASIL DAN PEMBAHASAN}

\section{Kadar pH Susu}

Hasil analisis statistik menggunakan uji $\mathrm{t}$ diperoleh perbedaan yang tidak nyata $(\mathrm{P}>0,05)$ dengan SNI pada $\mathrm{pH}$ susu di Medan Sunggal I (Tabel 1). Nilai pH sampel susu yang diamati bervariasi mulai dari 5,796,53 . Sebanyak 11 sampel susu $(73,3 \%)$ yang diamati lebih rendah nilainya dibandingkan dengan SNI 3141.1 (2011) yang menyatakan
pH susu adalah 6,3-6,8.

Sebanyak 4 sampel $(26,7 \%)$ yang diamati berada dalam kondisi layak, sedangkan 11 sampel $(73,3 \%)$ pada kondisi tidak layak konsumsi karena nilai pH-nya berada di bawah standar. Kondisi ini dapat disebabkan karena perlakuan susu yang tidak benar yaitu tidak melakukan pasteurisasi dan kondisi kandang pemerahan yang tidak terawat. Hal ini dapat menurunkan kualitas produk karena produk dapat tercemar melalui udara ataupun lingkungan tempat pemerahan. Selain itu, produk tidak dimasukkan ke dalam milk can dan tidak langsung disimpan pada suhu rendah.Hal ini sejalan dengan pendapat Rachmawan (2001) bahwa susu yang diperah, disaring, kemudian susu dimasukkan ke dalam milk can dan disimpan pada suhu rendah yaitu $4^{\circ} \mathrm{C}$ sambil menunggu pengiriman ke rumah industri.

Hal lain yang dapat mempengaruhi kualitas susu khususnya $\mathrm{pH}$ adalah masa penyimpanan. Masa penyimpanan sampel yang diamati sudah lebih dari 2 jam, sehingga nilai $\mathrm{pH}$ sampel turun menjadi asam (dibawah $\mathrm{pH}$ 6). Hal ini didukung oleh penelitian Umar et al. (2014) yang menyatakan bahwa lama penyimpanan dapat menurunkan angka reduktase dan derajat keasaman $(\mathrm{pH})$ susu sapi pasteurisasi. Selain itu, penanganan susu yang salah juga dapat meningkatkan pertumbuhan mikroorganisme pada susu. Kondisi asam produk dapat menandakan adanya kontaminasi bakteri. Hal ini didukung oleh Zakaria et al. (2013) yang menyatakan bahwa mikroorganisme sangat cepat berkembang pada susu karena produk ini memiliki nilai gizi yang tinggi yang mengakibatkan waktu penyimpanan yang singkat bila tidak ditangani dengan benar. Produk susu yang tidak layak konsumsi disebabkan oleh aktivitas pembusuk asam laktat seperti Streptococcus thermophiles, Lactobacillus lactis, dan Lactobacillus thermophiles. Penurunan $\mathrm{pH}$ susu disebabkan oleh bakteri asam laktat yang berperan memecah laktosa menjadi asam laktat. Pernyataan ini didukung oleh Buckle et al. (2007) bahwa bakteri 
Tabel 1. Kadar pH, angka reduktase, uji titik didih, dan uji alkohol susu

\begin{tabular}{lcccc}
\hline Kode Sampel & $\mathrm{pH}$ & Angka Reduktasi (Menit) & Uji Titik Didih & Uji Alkohol \\
\hline S1 & 6,18 & 60 & Negatif & Negatif \\
S2 & 6,02 & 60 & Negatif & Negatif \\
S3 & 6,20 & 60 & Negatif & Negatif \\
S4 & 6,10 & 60 & Negatif & Negatif \\
S5 & 6,12 & 60 & Negatif & Negatif \\
S6 & 6,05 & 60 & Negatif & Negatif \\
S7 & 6,14 & 60 & Negatif & Negatif \\
S8 & 6,18 & 60 & Negatif & Negatif \\
S9 & 5,95 & 45 & Positif & Positif \\
S10 & 5,79 & 45 & Positif & Positif \\
S11 & 5,83 & 30 & Positif & Positif \\
K1 & 6,34 & 90 & Negatif & Negatif \\
K2 & 6,53 & 150 & Negatif & Negatif \\
K3 & 6,44 & 60 & Negatif & Negatif \\
K4 & 6,42 & 60 & Negatif & Negatif \\
\hline SE & 0,77 & 6,93 & & \\
\hline
\end{tabular}

pembusuk asam laktat adalah Lactobacillus lactis, Lactobacillus thermophillus, dan Streptococcus thermophiles. Semakin tinggi aktivitas bakteri asam laktat pada saat pemecahan laktosa mengakibatkan turunnya nilai $\mathrm{pH}$ menjadi lebih asam.

\section{Angka Reduktase}

Berdasarkan hasil analisis statistik dengan uji $\mathrm{t}$ ditemukan perbedaan yang sangt nyata $(\mathrm{P}<0,01)$ dengan SNI susu pada saat dilakukan uji reduktase sampel. Aktivitas bakteri sampel susu yang diamati bervariasi adalah 30 hingga 150 menit (Tabel 1). Semakin tinggi aktivitas bakteri, akan semakin singkat waktu yang dibutuhkan untuk mengembalikan warna susu menjadi normal kembali. Sebaliknya, apabila waktu yang dibutuhkan lama, maka susu tersebut dalam keadaan baik atau segar. Hal ini sejalan dengan penelitian Umar et al. (2014) yang melakukan penelitian pada susu sapi pasteurisasi dan selama 7 hari masa penyimpanan sampel masih memiliki angka reduktase yang baik. Hal ini menunjukkan bahwa angka reduktase susu pasteurisasiakan menurun dengan masa penyimpanan yang semakin lama.

Keaktivan enzim reduktase pada reagen methylene blue menunjukkan tingginya aktivitas mikroorganiseme dala susu. Hal ini ditunjukkan dengan perubahan warna biru menjadi putih yang sangat cepat. Sesuai dengan pendapat Fardiaz (1989) yang menyatakan perubahan warna biru menjadi putih pada sampel susu akan semakin cepat apabila jumlah bakteri semakin meningkat.

Hal ini disebabkan oksigen yang dikonsumsi oleh mikroorganisme yang tumbuh dan dapat beraktivitas pada saat reagen methylene blue yang dicampurkan ke dalam sampel sehingga mengakibatkan perubahan warna menjadi putih. Hal ini sesuai dengan pendapat Buckle et al. (2007), bahwa dalam susu terdapat enzim reduktase yang dihasilkan oleh kuman-kuman. Perubahan warna biru pada reagen methylene blue menjadi tidak berwarna akibat adanya enzim ini. Oleh karena itu, untuk mengetahui mutu susu dengan cepat dapat menggunakan uji reduktase pada sampel. Sesuai dengan pendapat Hadiwiyoto (1994) bahwa mutu 
susu yang dapat diterima apabila warna biru reagen hilang pada masa simpan lebih dari 2 jam dan kurang dari 6 jam hingga dan jumlah mikroorganisme berkisar 4-20 juta.

Hasil penelitian ini berbeda dengan penelitian Yudonegoro et al. (2014) yang membedakan lama reduktase sampel susu dari peternak dan TPS dengan hasil masingmasing berurutan 7,43 jam dan 6,83 jam. Hasil ini berbeda dengan penelitian Susilawati et al. (2013) yang melakukan penelitian reduksi bakteri akibat pemanasan yang menunjukkan hasil bahwa aktivitas bakteri dapat menurun apabila dilakukan pemanasan.

Perbedaan hasil pada penelitian ini disebabkan karena adanya faktor kontaminasi yang mencemari susu dari manajemen pemeliharaan yang kurang baik, kandang yang tidak dibersihkan sebelum melakukan pemerahan, tempat penampungan kotoran yang dekat dnegan tempat pemerahan, sanitasi dan higiene peralatana, susu tidak dipasteurisasi dan perlakuan penyimpanan pada peralatan pemerahan yang masih kurang baik. Hal ini didukung oleh Sudono et al. (2003) bahwa kualitas susu dapat diperngaruhi oleh lingkungan sekitar kandang yang tidak bersih. Beberapa faktor yang mencemari susu seperti kandang yang kotor, menempelnya feses pada bagian ambing, urin dan berbagai kotoran lainnya dalam kandang.

Kontaminasi mikroorganisme dapat terjadi mulai dari hulu hingga ke hilir perlakuan terhadap produk. Selain itu, susu yang diperoleh dari outlet-outlet tidak diperlakukan dengan benar, yaitu melakukan pendinginan sehingga megakibatkan tinggi aktivitas bakteri dalam produk sehingga didapatkan nilai reduktase yang tinggi. Sesuai dengen Ismanto et al. (2013) yang menyatakan bahwa pertumbuhan mikroba perusak dapat dicegah melalui proses pendinginan agar dapat memperpanjang masa simpan susu. Menurut Rofi'i (2009) bahwa penghambatan pertumbuhan bakteri dan aktivitas enzimatisnya lebih efketif dengan perlakuan penyimpanan sampel susu pada suhu rendah $\left(10^{\circ} \mathrm{C}\right)$ dibandingkan penyimpanan pada suhu ruang. Selain itu, masa simpan produk juga mempengaruhi aktivitas bakteri pada produk. Hal ini sesuai dengan pendapat Umar et al. (2014) bahwa angka reduktase dan derajat keasaman $(\mathrm{pH})$ susu akan dipengaruhi oleh lama penyimpanan.

Reagen MB yang digunakan akan diubah menjadi warna putih kembali. Dasar penentuan jumlah bakteri pada sampel adalah waktu perubahan warna biru menjadi putih. Aktivitas enzim pada bakteri tertentu dalam susu menyebabkan daya reduksi reduksi muncul. Banyak penelitian yang sudah membuktikan bahwa besarnya daya reduksi dan jumlah bakteri dalam susu berhubungan. Oleh karena itu, salah satu prosedur yang digunakan untuk mengetahui mutu susu adalah uji daya reduksi baik dalam kondisi segar atau pasteurisasi. Perbedaan kekuatan oksidasi reduksi sebesar $300 \mathrm{mV}$ menjadi disebabkan oleh kontak susu pada saat diperah dengan udara. Hal ini sekaligus menjadi dasar pengujian uji reduksi. Oksigen dibutuhkan oleh bakteri dalam susu agar dapat tumbuh dan akan menghasilkan substansi pereduksi.

\section{Uji Titik Didih}

Hasil uji titik didih sampel susu seperti pada Tabel 1. Pada penelitian yang dilakukan, $80 \%$ sampel yang diamati menunjukkan hasil negatif. Hasil ini sesuai dengan standar susu segar. Pada SNI (2011) menyatakan bahwa persyaratan kualitas susu yaitu uji didih negatif. Dari hasil uji didih yang diperoleh menunjukkan bahwa susu sapi yang digunakan sebagai sampel khususnya daerah Medan Sunggal masih berkualitas bagus serta layak dikonsumsi karena tidak terjadi pemalsuan susu.

\section{Uji Alkohol}

Pada penelitian yang dilakukan, $80 \%$ sampel yang diamati menunjukkan hasil negative yaitu tidak ada penggumpalan yang terjadi pada susu yang ditetesi dengan alkohol (Tabel 1). Hasil ini sesuai dengan standar susu segar. Pada SNI (2011) menyatakan bahwa persyaratan kualitas susu yaitu uji alkohol 70\% negatif. Dari hasil uji alkohol 
Tabel 2. Uji organoleptik warna, aroma, dan rasa susu

\begin{tabular}{lccc}
\hline Kode Sampel & Karakteristik Warna & Karakteristik Aroma & Karakteristik Rasa \\
\hline S1 & Putih Kekuningan & Khas Sapi & Gurih, sedikit asin \\
S2 & Putih Kekuningan & Khas Sapi & Gurih, sedikit asin \\
S3 & Putih Kekuningan & Khas Sapi & Gurih, sedikit asin \\
S4 & Putih Kekuningan & Khas Sapi & Gurih, sedikit asin \\
S5 & Putih Kekuningan & Khas Sapi & Gurih, sedikit asin \\
S6 & Putih Kekuningan & Khas Sapi & Gurih, sedikit asin \\
S7 & Putih Kekuningan & Khas Sapi & Gurih, sedikit asin \\
S8 & Putih Kekuningan & Khas Sapi & Gurih, sedikit asin \\
S9 & Putih Kekuningan & Khas Sapi & Gurih, sedikit asin \\
S10 & Putih Kekuningan & Khas Sapi & Gurih, sedikit asin \\
S11 & Putih Kekuningan & Khas Sapi & Gurih, sedikit asin \\
K1 & Putih Kekuningan & Khas Kambing & Gurih, sedikit asin \\
K2 & Putih Kekuningan & Khas Kambing & Gurih dan sedikit berlemak, \\
& & & sedikit asin \\
K3 & Putih Kekuningan & Khas Kambing & Gurih dan sedikit berlemak, \\
& & & sedikit asin \\
K4 & Putih Kekuningan & Khas Kambing & Gurih dan sedikit berlemak, \\
& & & sedikit asin \\
\hline
\end{tabular}

yang diperoleh menunjukkan bahwa susu sapi yang digunakan sebagai sampel khususnya daerah Medan Sunggal masih berkualitas bagus serta layak dikonsumsi karena tidak terjadi pemalsuan susu. Susu yang dijadikan sebagai sampel penelitian memiliki rata-rata waktu 2-4 jam penyimpanan. Hasil penelitian ini sejalan dengan penelitan yang dilakukan Nababan et al. (2015) bahwa kualitas susu cair semakin tidak layak untuk dikonsumsi apabila disimpan pada suhu ruang dalam waktu yang lama.

\section{Uji Organoleptik}

\section{Warna}

Warna merupakan pengamatan menggunakan indera penglihatan (mata) terhadap kenampakan sampel. Pengamatan warna susu yang dilakukan sesuai dengan SNI (2011) yaitu warna susu segar adalah putih kekuningan. Berdasarkan hasil penelitian pada 15 sampel susu, warna susu yang diperoleh baik susu sapi dan kambing adalah putih kekuningan (normal) (Tabel 2). Kondisi ini menandakan susu dalam kondisi baik atau tidak mendapatkan perlakuan menyimpang.

Warna putih kekuningan susu berasal dari kasein. Pada susu, kasein berwarna putih seperti salju, tidak tembus cahaya karena merupakan disfersikoloid(Buckle etal.,2007). Selain kasein, susu mengandung karoten yang mengakibatkan produk ini kadang-kadang berwarna kekuningan. Karoten merupakan pigmen kuning utama yang berasal dari lemak susu. Apabila zat ini termetabolisme di dalam tubuh manusia akan membentuk dua molekul. Karotenoid hanya disintesa oleh tumbuhan dan sangat dibutuhkan sekali dalam pakan ternak perah. Beberapa faktor yang mempengaruhi banyaknya karoten dalam susu adalah bangsa, spesies, individu, masa laktasi, umur, dan pakan hijauan yang dikonsumsi oleh ternak. Diperkuat oleh Navyanti dan Adriyani (2015) bahwa warna, rasa dan bau tidak akan terpengaruh apabila tidak ada kontaminasi benda asing seperti antibiotik ataupun residu obat-obatan pada susu. 


\section{Aroma}

Organoleptik susu yang diamati selain warna adalah aroma susu. Aroma susu yang diperoleh pada penelitian ini adalah aroma yang normal yaitu khas pada jenis ternak yang digunakan (Tabel 2).

Hasil ini sesuai dengan SNI (2011) yang menyatakan bahwa aroma normal susu adalah khas jenis ternak itu sendiri. Apabila ditemukan perubahan atau penyimpangan aroma susu, menunjukkan bahwa susu sudah mengalami pemalsuan. Pada sampel penelitian, tidak ditemukan perbedaan atau penyimpangan pada aroma susu.

\section{Rasa}

Rasa merupakan salah satu organoleptik yang diamati pada penelitian. Rasa susu normal adalah rasa gurih yang berasal dari lemak susu dan protein yang terkandung didalamnya. Hasil penelitian menunjukkan bahwa rasa susu pada sampel susu sapi adalah gurih, asin, sedangkan rasa susu kambing agak sedikit lebih berlemak dan sedikit asin (Tabel 2). Hal ini dipengaruhi oleh jenis ternak penghasil susu yang digunakan.

Hasil ini sesuai dengan SNI yang menyatakan bahwa rasa normal susu adalah gurih dan sedikit berlemak. Apabila ditemukan perubahan atau penyimpangan rasa susu, menunjukkan bahwa susu sudah mengalami pemalsuan atau susu sudah dalam kondisi tidak segar. Pada sampel penelitian, tidak ditemukan perbedaan atau penyimpangan pada aroma susu.

\section{KESIMPULAN}

Kesimpulan yang dapat diperoleh dari hasil penelitian adalah sampel susu yang diambil dari peternak dan outlet susu di Medan Sunggal tidak sesuai dengan SNI 3141.1.

\section{DAFTAR PUSTAKA}

Badan Standarisasi Nasional. 2011. SNI 3141.1 Susu Segar-Bagian 1: Sapi.
Badan Standarisasi Nasional (BSN), Jakarta.

Buckle, K. A., R. A. Edwards., G. H. Fleet, dan M. Wooton. 2007. Ilmu Pangan. Universitas Indonesia Press, Jakarta.

Fardiaz, S. 1989. Mikrobiologi Pangan. PAU Pangan dan Gizi. IPB. Bogor.

Hadiwiyoto. 1994. Pengujian Mutu Susu Dan Hasil Olahannya. Yogyakarta: Liberty. Hal: 5.

Ismanto, T., S. Utami, dan H. A. Suratim. 2013. Pengaruh Lama Penyimpanan Dalam Refrigerator terhadap Berat Jenis dan Viskositas Susu Kambing Pasteurisasi. Agrocientiae. Jurnal Ilmiah Peternakan. 1(1): 69-78.

Masrizal. 2010. Modul Ajar Statistika II. Fakultas Peternakan Universitas Andalas, Padang.

Navyanti, F. dan R. Adriyani. 2015. Higiene sanitasi, kualitas fisik dan bakteriologi susu sapi segar perusahaan susu $x$ di Surabaya. Jurnal Kesehatan Lingkungan. 8(1): 36-47.

Pratiwi, D. A. 2018. Personal higiene pemerah susu Sapi dan pemeriksaan kandungan Salmonella sp. pada susu sapi perah dari beberapa lokasi peternakan sapi perah di Kota Medan tahun 2017. Skripsi. Repositori Institusi USU, Medan.

Rachmawan, O. 2001. Modul Program Keahlian Teknologi Hasil Pertanian Penanganan Susu Segar. Departemen Pendidikan Nasional, Bandung.

Rofi'I, F. 2009. Hubungan Antara Jumlah Total Bakteri dan Angka Katalase Terhadap daya Tahan Susu. Fakultas Kedokteran Hewan. Institut Pertanian Bogor. Skripsi. IPB Repository.

Sudono, A., R. F. Rosdiana, dan B. S. Setiawan. 2003. Beternak Sapi Perah Secara Intensif. Agromedia Pustaka. Jakarta.

Susilawati, T., S. B. M. Abduh, dan S. Mulyani. 2013. Reduksi bakteri dan biru metilen, serta perubahan intensitas pencoklatan 
dan $\mathrm{pH}$ susu akibat pemanasan pada suhu $80^{\circ}$ dalam periode yang bervariasi. Animal Agriculture Journal. 2(3): 123131.

Umar, Razali, dan A. Novita. 2014. Derajat keasaman dan angka reduktase susu sapi pasteurisasi denngan lama penyimpanan yang berbeda. Jurnal Medika Veterinaria. 8(1).

Yudonegoro, R. J., Nurwantoro, dan D. W. Harjanti. 2014. Kajian Kualitas Susu
Segar dari Tingkat Peternak Sapi Perah, Tempat Pengumpulan Susu dan Koperasi Unit Desa Jatinom di Kabupaten Klaten. Animal Agriculture Journal. 3(2): 323-333.

Zakaria, Y., Yurliasni., M. Delima, dan E. Diana. 2013. Analisa Keasaman dan Total Bakteri Asam Laktat Yogurt Akibat Bahan Baku dan Persentase Lactobacillus casei yang Berbeda. Agripet. 13(2): 31-35. 